fields. Some unevenness is perhaps inevitable in a book of this kind, and this one does not entirely escape it. The discussions on serological tests for rheumatoid arthritis and on tests for thyroid activity are on a more detailed level than other chapters and will be rather hard to follow for those not familiar with the techniques. It is also surprising to find that examination of the urine is limited to bacteriology. Space should certainly be found in future editions for chemical testing of urine and for a brief mention of paper chromatography, if necessary at the expense of renal function tests. The chapter on marrow puncture also appears to advocate the procedure somewhat too readily and is slightly at variance with the advice in the chapter on blood examination that clinical appraisal, a hæmoglobin level and a blood film examination will go far to establish a diagnosis in blood diseases.

The criticisms, however, do not prevent the book from succeeding largely in its aim. This, as stated in the foreword by Professor Cruickshank, is to encourage general practitioners to investigate their patients themselves by using the local hospital and public health laboratory facilities directly. He says that only I $_{5}$ to $20 \%$ do so ' regularly and intelligently' even where local facilities are available. If more can be induced to do so by this book, the modest price will be money well spent.

\section{Aspects of Psychotherapy}

I. Atkin. Pp. vii + 103. Edinburgh and London: E. \& S. Livingstone. I962. ros. $6 d$.

The objective of this little book is to stimulate those who are on the brink of a psychiatric career and to be helpful to those general practitioners who can spare time for psychotherapy. It consists of a series of essays, most of them previously published in leading medical journals. About half of them deal with problems of psychotherapy, the remainder range over such topics as shock therapy and leucotomy, assessment of recovery rates in schizophrenia, 'difficult delusions', and an excellent commentary on Dostoevsky's psychological understanding. The lightness of the approach is illustrated by the fact that the book starts and finishes in verse, but it is everywhere clear in style and particularly realistic in the chapters on psychotherapy. The author has achieved his objective.

\section{Medicine and the Navy, I200-I900}

Volume IV, 1815-1900. C. Lloyd and J. L. S. Coulter. Pp. $300+x i$, 13 illustrations. Edinburgh and London: E. \& S. Livingstone. 1963. 50 .

This volume completes the great work on the history of the Medical Service of the Royal Navy originally started by the late Surgeon-Commander J. J. Keevil. Owing to his untimely death, Commander Keevil was only able to complete the first two volumes, but, as in the third volume, the present authors have ably maintained the original high standard, and to them is due high praise for the manner in which they have completed the task entrusted to them.

In this volume the subject is not considered chronologically, but is divided into chapters concerned with the various aspects of the Naval Medical Service. Thus there are chapters on the Surgeon, Victualling, Fevers, the Royal Naval Hospitals, etc., in each one of which the development of the particular aspect of
Service life and methods is considered throughout the period concerned. This method of presentation makes the development of the various aspects of the work of the Service much more comprehensible, and has the additional advantage that each chapter is in itself a fascinating study. In that it follows the development of the Naval Medical Service into the modern era of medicine this book contains much that will be of interest to all those who have served in the Medicalc Branch of the Royal Navy, but it will also appeal to wider audience. The chapters dealing with the Crimean War, the convict ships, the Arctic voyages and the last phase of the scurvy story, the introduction of preserved. food, all these and others beside are packed with? fascinating, authentic information which will appeal to $\vec{A}$ all medical men with an interest in the past. Writtenc in clear, simple prose the book is easy to read and at the same time is a work of real scholarship and authority

Taken together these four volumes indubitably con- 3 . stitute the definitive history of the Royal Naval Medical Service, and it is difficult to believe that they will bece supplanted. In the breadth and detail of their scholar- $c$ ship these volumes are a worthy tribute to their distinguished original author and to his most able successors:'; the story they tell is an abiding memorial to the courage and devotion of the men who have guarded the health of the Royal Navy throughout the centuries.

\section{Disease in Infancy and Childhood}

R. W. B. Ellis. Fourth edition. Pp. vii $+717 \frac{\bigcirc}{0}$ illustrated. Edinburgh and London: E. \& S. O Livingstone. 1963 . 60s.

This well-known textbook of Pædiatrics was firखst $\vec{\varphi}$ published in 195 $\mathrm{I}$, since then it has gained mas devotees and it has now entered its fourth edition. $\Phi_{t}$. comprises 717 pages and although the book is deceptivefy light, the printing and layout are of a high standard. Extensively illustrated, there are 3 OI figures, many of them in colour; the latter are especially noteworthy for the subject matter and good colour reproduction. $\frac{2}{\bar{D}}$ A praiseworthy feature is the inclusion of a number of $\Omega$ recent references at the end of chapter. The subject $\overrightarrow{\vec{O}}$ matter is comprehensive and touches on most fields of $\frac{\bar{O}}{3}$ pædiatric interest. Almost a third of the text is devoted to the newborn and to congenital malformations.

Inevitably there are some criticisms, in particular? the omission of the Apgar method of assessment of the newborn and the general treatment of resuscitation will not meet with universal approval. The section on sclerma perpetuates the confusion surrounding the nomenclature of this condition. It is surprising that no mention of barrier creams nor of simple exposure is $\delta$ made in the management of napkin eruptions; the description of lead poisoning would have been enhanced by the inclusion of the coproporphyrin test. It is unfortunate that such prominence has been given to $D$ 'cutting down' for intravenous infusion in a pædiatric 을 textbook.

It is becoming increasingly difficult for this rapidly $\mathrm{N}$ expanding subject to be adequately represented by a $\mathrm{N}$ single author, nevertheless in a book of this type benefit accrues from the consistent style and lack of duplication. $N$ On balance it may be concluded that this book probably $\sigma$ represents the best available text for those embarking upon the study of pædiatrics and it retains much interest for all those who are called upon to treat children 